\title{
Economic Impact of Cleghorn Springs State Fish Hatchery, Rapid City, South Dakota, USA
}

\author{
Shaylee Martling1, Brian Fletcher', Michael E. Barnes ${ }^{2 *}$ \\ ${ }^{1}$ South Dakota Department of Game, Fish and Parks, Cleghorn Springs State Fish Hatchery, Rapid City, SD, USA \\ ${ }^{2}$ South Dakota Department of Game, Fish and Parks, McNenny State Fish Hatchery, Spearfish, SD, USA \\ Email: *mike.barnes@state.sd.us
}

How to cite this paper: Martling, S., Fletcher, B., \& Barnes, M. E. (2020). Economic Impact of Cleghorn Springs State Fish Hatchery, Rapid City, South Dakota, USA. Modern Economy, 11, 1351-1358. https://doi.org/10.4236/me.2020.117096

Received: June 11, 2020

Accepted: July 19, 2020

Published: July 22, 2020

Copyright $\odot 2020$ by author(s) and Scientific Research Publishing Inc. This work is licensed under the Creative Commons Attribution International License (CC BY 4.0).

http://creativecommons.org/licenses/by/4.0/

(c) (i) Open Access

\begin{abstract}
Cleghorn Springs State Fish Hatchery, Rapid City, South Dakota, USA is a public fish hatchery producing trout and salmon for recreational angling in South Dakota. Funding for the hatchery comes from an excise tax on fishing equipment and the sale of hunting and fishing licenses. This study is an assessment of the local economic effect of hatchery expenditures and fish production for 2019. Fish reared at Cleghorn Springs State Fish Hatchery in 2019 had a calculated total economic impact value of $\$ 5,105,825.89$. This value was added to Cleghorn Springs estimated share of angler expenditures in the Black Hills National Forest, increasing the total local monetary impact to $\$ 89,405,101.86$. Cleghorn Springs State Fish Hatchery generated $\$ 171.93$ of local economic output per budgetary dollar spent in 2019.
\end{abstract}

\section{Keywords}

Fish Hatchery, Economic Impact, Recreational Fishing

\section{Introduction}

Fishing is the second most popular form of outdoor recreation in the United States (OIA, 2018), and is an important part of the United States economy (BEA, 2018). In 2018, 49.4 million Americans participated in fishing, continuing an upward trend in the number of participants since 2007 (OIA, 2019). Almost $\$ 50$ billion (USD) in retail sales was generated by these anglers, affecting the income of more than 800,000 people (USFWS \& USCB, 2018).

Aquaculture production by publicly-owned hatcheries is essential for recreational fishing, as well as the management, conservation, and restoration of fisheries and fishes in the United States (Jackson et al., 2004, USFWS, 2020). For example, in 2019 the United States Fish and Wildlife Service produced and re- 
leased over 230 million adult and juvenile fishes and eggs from 70 federal hatcheries into the waters of 46 states (USFWS, 2020). Most state governments also own and operate public fish hatcheries for recreational fish stocking including Wisconsin, which operates 17 fish hatcheries and rearing facilities, stocking millions of fish into hundreds of state waters

(https://nnr.wi.gov/topic/fishing/hatcheries/index.html), Colorado, which operates 19 hatcheries producing 90 million fish per year for stocking into public fishing waters (https://cpw.state.co.us/hatcheries), New York, which operates 12 hatcheries producing 2.3 million catchable-size trout

(http://www.dec.ny.gov/outdoor/7742.html), and Texas, which operates 3 saltwater and 5 freshwater hatcheries, growing and stocking nearly 40 million fish each year (https://tpwd.texas.gov/fishboat/fish/management/stocking/). The state of Oregon operated 32 hatcheries, producing nearly 44 million fish and employing 166 permanent employees in 2018 (Chilton \& Garza, 2019). In 2013, government-run hatcheries produced nearly $29,000 \mathrm{t}$ of fish for recreational purposes, over half of which was rainbow trout (Oncorhynchus mykiss) (USDA, 2014). Rainbow trout are one of the most commonly stocked fish in North America, most often being stocked at a catchable size (Kerr \& Lasenby, 2000; MacCrimmon, 1971). Hatchery-reared fish, such as rainbow trout and other salmonids, stocked into public fishing waters, can have considerable economic benefits (Johnson \& Walsh, 1987; Caudill, 2005, 2007; USFWS, 2006).

In the United States, the State of South Dakota owns and operates two trout and salmon hatcheries: Cleghorn Springs State Fish Hatchery in Rapid City and McNenny State Fish Hatchery near Spearfish. Neither trout nor salmon are native to South Dakota (Barnes, 2007). Natural reproduction is limited, except in select Black Hills streams where brown trout (Salmo trutta) and brook trout (Salvelinus fontinalis) reproduce, making recreational fishing for trout and salmon in South Dakota largely dependent upon hatchery-reared fish. Hatchery fish stocking provides nearly all of the rainbow trout, and absolutely all of the Chinook salmon (Oncorhynchus tshawytscha), caught by recreational anglers in South Dakota. From July 1, 2018 to June 30, 2019, 572,091 trout and salmon produced at Cleghorn Springs and McNenny State Fish Hatcheries were stocked into public fishing waters in South Dakota (SDGFP, 2019a).

Barnes and Palmer (2019) conducted one of the few economic analyses on an individual state fish hatchery. Economic impacts have been quantified for trout production on the federal level in the United States (USFWS, 2006) and for individual fisheries maintained by hatchery-produced fish (Johnson \& Walsh, 1987; Caudill, 2007). Understanding the economic impacts of public hatchery operations is extremely important, given the stewardship obligations of government agencies, such as the South Dakota Game, Fish and Parks (SDGFP, 2015). The objective of this study was to assess the economic impact of fish production at Cleghorn Springs State Fish Hatchery on the local economy in South Dakota. 


\section{Methods}

Cleghorn Springs State Fish Hatchery in Rapid City, South Dakota, USA, expenditures, fish production, and fish stocking data were used to evaluate the local (within South Dakota) economic impact of the hatchery using the following methodology, which was originally developed by Barnes and Palmer (2019). Actual expenditure data from 2019, minus out-of-state expenditures, was used for the economic analysis. Local spending included the wages and benefits paid to permanent and temporary hatchery employees, in-state travel, supplies (e.g. office supplies, hardware, building and grounds cleaning and maintenance, etc.), fuel, equipment, and other materials purchased from South Dakota vendors, as well as utility costs and services provided by local contractors (Table 1). Capital was put back into South Dakota businesses and directly reinvested into the local economy, therefore this data was considered local economic output. Expenditures for fish food, computer hardware, and specialized scientific equipment procured from out-of-state vendors, were excluded, in addition to any large, one-time construction project expenditures (Barnes and Palmer, 2019).

The values of all of the fish from the hatchery stocked in 2019 were included in the analysis along with the local expenditures. Because Cleghorn Springs State Fish Hatchery is funded entirely from the sale of fishing licenses and an excise tax on fishing equipment, all of the rainbow trout, Atlantic salmon (Salmo salar), and Chinook salmon (Oncorhynchus tshawytscha) stocked in 2019 went into public fishing waters within the state of South Dakota (Barnes \& Palmer, 2019; SDGFP, 2019a).

The trout stocked were assigned a base dollar value, using the values obtained by Johnson and Walsh (1987) on what an angler would be willing to pay for each fish, and adjusted to current Consumer Price Index (CPI) Standards (BLS, 2020). Rainbow trout and Atlantic salmon are stocked into public fishing waters at a catchable size to provide for immediate recreation (Johnson et al., 1995; Barnes et al., 2009). Atlantic Salmon were considered as trout in this analysis because of the relatively small number produced and the similarity in production size and purpose to that of the rainbow trout. Dalton et al. (1998) found anglers are willing to pay more for larger fish and Whitehead and Aiken (2007) estimated this increase to be $3.5 \%$ more per $\mathrm{cm}$ in trout length greater than $23 \mathrm{~cm}$, therefore

Table 1. Cleghorn springs state fish hatchery expenditures (USD) in 2019 by category.

\begin{tabular}{cc}
\hline Expenditure Category & Amount (\$) \\
Salaries & 250,044 \\
Benefits & 78,768 \\
In-state travel & 1,419 \\
Services and utilities & 121,377 \\
Supplies & 68,411 \\
Total & $\$ 520,019$ \\
\hline
\end{tabular}


the inflation-adjusted base value was increased accordingly for the rainbow trout and Atlantic salmon at each stocking size. For the economic value of the trout stocked, the value of the expenditures per day for anglers in the Black Hills National Forest of South Dakota (\$74.93/day, and a total of 2,984,192 angler days per year) was multiplied by the percent share $(37.7 \%)$ of the fish stocked from Cleghorn Springs hatchery of all the fish stocked in the Black Hills National Forest (Barnes \& Palmer, 2019; ASA, 2007).

Chinook salmon production differs from the other fish species because they are stocked at a much smaller size and expected to grow for several years before being caught by recreational anglers (Barnes \& Palmer, 2019). The economic value $(\$ 6,091,482)$ of the Chinook salmon fishery was determined by multiplying the number of angler trips $(22,752$; Johnson et al., 1996) by the average spending per trip (\$75; USFWS, 1997) and adjusting for inflation according to current CPI standards (BLS, 2020). The Chinook salmon fishery total value was then multiplied by the percentage (73.1\%) of the total salmon raised and stocked by Cleghorn Springs hatchery (Barnes \& Palmer, 2019). A per-fish value was created by dividing the percentage of the total Chinook salmon economic value attributable to Cleghorn Springs hatchery by the number of fish stocked.

The values for each size and species of fish were added to produce the total value of fish stocked by Cleghorn Springs State Fish Hatchery. This value was then added to the share of angler expenditures in the Black Hills attributed to the hatchery to obtain the total local economic impact. The total local economic impact was divided by the annual local budgetary expenditures of Cleghorn Springs Hatchery to obtain the economic impact per dollar spent.

\section{Results}

The total local economic impact of Cleghorn Springs State Fish Hatchery in 2019 was estimated to be nearly $\$ 89.5$ million USD (Table 2). The total value of the fish raised at Cleghorn Springs State Fish Hatchery was calculated to be $\$ 5,105,825.89$ (Table 3 ), and the local economic impact per budgetary dollar spent for Cleghorn Springs State Fish Hatchery was estimated to be $\$ 171.93$.

\section{Discussion}

The calculation of $\$ 171.93$ per budget dollar expenditure of economic impact for

Table 2. Economic impact (USD) of Cleghorn springs state fish hatchery fish production and stocking on local South Dakota, USA, economies, and impact per dollar spent.

\begin{tabular}{cc} 
Category & Value (\$) \\
\hline Fish stocked & $5,105,825$ \\
Share of Black Hills angler expenditures & $84,299,275$ \\
Total economic impact & $89,405,101$ \\
Hatchery budgetary expenditures & 520,019 \\
Economic impact/budgetary dollar spent & $\$ 171.93$
\end{tabular}


Table 3. Number, sizes, and species of catchable sized fish stocked from Cleghorn springs state fish hatchery in 2019, along with base values (USD) per fish.

\begin{tabular}{ccccc}
\hline Species & Size $(\mathrm{cm})$ & Number & Base value $(\$)$ & Total value $(\$)$ \\
\hline Rainbow trout & 28 & 103,584 & 5.91 & 612,181 \\
Rainbow trout & 38 & 2,638 & 12.25 & 32,315 \\
Atlantic salmon & 33 & 989 & 8.55 & 8,456 \\
Chinook salmon & n/a & 211,828 & 21.00 & $4,452,873$ \\
Total & & 319,039 & & $\$ 5,105,826$ \\
\hline
\end{tabular}

Cleghorn Springs hatchery exceeds, but is relatively close to, the inflation-adjusted economic impacts ranging from $\$ 115$ to $\$ 148$ for each hatchery budgetary dollar reported from hatcheries producing catchable-size trout in the heavily-populated southeastern portion of the United States (USFWS, 2001). These results are comparable because of the high angling pressure for trout by both a large number of residents and an exceptionally large number of non-residents during the summer in the Black Hills (ASA, 2007). In addition, stocking Chinook salmon far from their native ocean habitats in a completely landlocked reservoir has created a popular and unique angling opportunity for anglers from South Dakota as well as many neighboring states.

The economic impact per budgetary dollar spent at Cleghorn Springs State Fish Hatchery is much more than the economic impact of $\$ 47.94$ per budget dollar spent calculated for hatcheries operated by the U.S. Fish and Wildlife Service (USFWS, 2006). This may be because federal stockings are occurring over a much larger area, including locations with relatively low human population densities and angling pressure. The values for Cleghorn Springs are also much larger than the $\$ 51.68$ estimated by Barnes and Palmer (2019) for the nearby McNenny State Fish Hatchery, which also stocks trout in the Black Hills and salmon in South Dakota. This discrepancy was because of a decimal place error during multiplication by Barnes and Palmer (2019). Correcting this miscalculation would greatly increase the estimated economic impact, making it even greater than the $\$ 171.93$ per budget dollar expenditure calculated for Cleghorn Springs hatchery in the present study.

The economic impact of Cleghorn Springs Hatchery identified in this study affirms that the hatchery rearing of trout and salmon for recreational fishing creates substantial economic output across the United States (Johnson \& Walsh, 1987; Caudill, 2005, 2007; Charbonneau \& Caudill, 2010; Barnes \& Palmer, 2019). Of particular interest, the almost $\$ 89.5$ million in total local economic impact by Cleghorn Springs hatchery occurred without any funding from the general tax revenue of South Dakota state government (SDGFP, 2019b; Barnes \& Palmer, 2019). Thus, the user-pay model, whereby anglers fund hatchery operations by purchasing licenses and fishing equipment, is markedly financially benefiting the non-angling public. Both the direct and indirect economic impacts of fish and other forms of outdoor recreation are integral to the economy of 
South Dakota (Tourism Economics, 2017).

Because this study focused only on the local economic impact of Cleghorn Springs State Fish Hatchery, the overall economic impact is conceivably much greater. Recurring large expenditures going to out-of-state firms, such as fish food purchases, were excluded from this study. The impacts of relatively expensive construction projects were also excluded. In addition to these, almost half of the trout stocked by Cleghorn Springs State Fish Hatchery were stocked outside of the Black Hills in other parts of South Dakota. No summarized data on angler's daily expenditures for these other regions were found, therefore money spent on trout angling outside of the Black Hills was excluded from this analysis. Lastly, although difficult to quantify, there are certainly economic impacts due to hatchery research and innovation (Griliches, 1979; Williams \& Rank, 1998; Bessette, 2003). The continuing, substantial research output at Cleghorn Springs likely produces long-term economic benefits both within and well beyond the borders of South Dakota (Evenson, 2001; Salter \& Martin, 2001; Blanco et al. 2016).

The economic impact and cost-benefit data from this study compliment the information previously described for McNenny State Fish Hatchery (Barnes \& Palmer, 2019), providing a solid foundation for future budgeting and expenditure decision-making by hatchery and higher-level administrators. However, more accurate economic impact assessments could likely be achieved by conducting a large survey of anglers to determine more accurate values for willingness-to-pay per fish caught or willingness-to-pay for increases in fish size.

\section{Acknowledgements}

We thank Tim Palmer for his assistance with this study.

\section{Conflicts of Interest}

The authors declare no conflicts of interest regarding the publication of this paper.

\section{References}

ASA (American Sportfishing Association) (2007). State and National Economic Effects of Fishing, Hunting and Wildlife-Related Recreation on U.S. Forest Service-Managed Lands. https://www.fs.fed.us/biology/resources/pubs/wildlife/usfs wildlife based recreation e conomic contributions 103 07.pdf

Barnes, M. E. (2007). Fish Hatcheries and Stocking Practices: Past and Present. In C. Berry, K. Higgins, D. Willis, \& S. Chipps (Eds.), History of Fisheries and Fishing in South Dakota (pp. 267-294). Pierre, South Dakota: South Dakota Department of Game, Fish and Parks.

Barnes, M. E., \& Palmer, T. (2019). Economic Impact of McNenny State Fish Hatchery, Spearfish, SD, USA. Modern Economy, 10, 1581-1588.

https://doi.org/10.4236/me.2019.106104

Barnes, M. E., Simpson, G., \& Durben, D. J. (2009). Post-Stocking Harvest of Catchable-Sized Rainbow Trout Enhanced by Dietary Supplementation with a Fully Fer- 
mented Commercial Yeast Culture during Hatchery Rearing. North American Journal of Fisheries Management, 29, 1287-1295. https://doi.org/10.1577/M08-218.1

BEA (Bureau of Economic Analysis) (2018). Outdoor Recreation Satellite Account: Updated Statistics for 2012-2016.

https://www.bea.gov/news/2018/outdoor-recreation-satellite-account-updated-statistic s-2012-2016

Bessette, R. W. (2003). Measuring the Economic Impact of University-Based Research. Journal of Technology Transfer, 28, 355-361. https://doi.org/10.1023/A:1024917601088

Blanco, L. R., Gu, J., \& Prieger, J. E. (2016). The Impact of Research and Development on Economic Growth and Productivity in the US States. Southern Economic Journal, 82, 914-934. https://doi.org/10.1002/soej.12107

BLS (2020). Bureau of Labor Statistics. https://www.bls.gov/data/inflation calculator.htm

Caudill, J. (2005). The Economic Effects of Rainbow Trout Stocking by Fish and Wildlife Service Hatcheries in FY 2004. Arlington, VA: U.S. Fish and Wildlife Service, Division of Economics.

Caudill, J. (2007). The Economic Impacts of Trout Stocking on Tailwaters in the Southeast Aquatic Resources Partnership (SARP). Arlington, VA: U.S. Fish and Wildlife Service, Division of Economics.

Charbonneau, J. J., \& Caudill, J. (2010). Conserving America's Fisheries. An Assessment of Economic Contributions from Fisheries and Aquatic Resource Conservation. Arlington, VA: U.S. Fish and Wildlife Service, Division of Economics.

https://www.fws.gov/home/feature/2011/pdf/fisherieseconomicreport.pdf

Chilton, G., \& Garza, G. (2019). Fish Propagation Annual Report for 2018. Salem, OR: Fish Division, Oregon Department of Fish and Wildlife.

https://www.dfw.state.or.us/fish/hatchery/docs/2018\%20\%20Fish\%20Propagtion $\% 20 \mathrm{~A}$ nnual\%20Report.pdf

Dalton, R. S., Bastian, C. T., Jacobs, J. J., \& Wesche, T. A. (1998). Estimating the Economic Value of Improved Trout Fishing on Wyoming Streams. North American Journal of Fisheries Management, 18, 786-797. https://doi.org/10.1577/1548-8675(1998)018<0786:ETEVOI >2.0.CO;2

Evenson, R. E. (2001). Economic Impacts of Agricultural Research and Extension. In Handbook of Agricultural Economics (Vol. 1, pp. 573-628). Amsterdam: Elsevier. https://doi.org/10.1016/S1574-0072(01)10014-9

Griliches, Z. (1979). Issues in Assessing the Contribution of Research and Development to Productivity Growth. The Bell Journal of Economics, 10, 92-116. https://doi.org/10.2307/3003321

Jackson, J. R., Boxrucker, J. C., \& Willis, D. W. (2004). Trends in Agency Use of Propagated Fishes as a Management Tool in Inland Fisheries. American Fisheries Symposium, 44, 121-138.

Johnson, B., Lott, J., Nelson-Stastny, W., \& Riis, J. (1996). Annual Fish Population and Sport Fish Harvest Surveys on Lake Oahe, South Dakota 1996. Annual Report, 97-15. Pierre, SD: South Dakota Department of Game, Fish and Parks.

Johnson, D. M., \& Walsh, R. G. (1987). Economic Benefits and Costs of the Fish Stocking Program at Blue Mesa Reservoir, Colorado. Fort Collins, CO: Colorado Water Resources Research Institute.

Johnson, D. M., Behnke, R. J., Harpman, D. V., \& Walsh, R. G. (1995). Economic Benefits and Costs of Stocking Catchable Rainbow Trout: A Synthesis of Economic Analysis in Colorado. North American Journal of Fisheries Management, 15, 26-32. 
https://doi.org/10.1577/1548-8675(1995)015<0026:EBACOS>2.3.CO;2

Kerr, S. J., \& Lasenby, T. A. (2000). Rainbow Trout Stocking in Inland Lakes and Streams: An Annotated Bibliography and Literature Review. Peterborough, Ontario: Fish and Wildlife Branch, Ontario Ministry of Natural Resources.

MacCrimmon, H. R. (1971). World Distribution of Rainbow Trout (Salmo gairdneri). Journal of the Fisheries Research Board of Canada, 28, 663-704. https://doi.org/10.1139/f71-098

OIA (Outdoor Industry Association) (2018). Outdoor Participation Report. https://outdoorindustry.org/resource/2018-outdoor-participation-report/

OIA (Outdoor Industry Association) (2019). Special Report on Fishing. https://outdoorindustry.org/wp-content/uploads/2015/03/2019-Special-Report-on-Fish ing RBFF FINAL1.pdf

Salter, A. J., \& Martin, B. R. (2001). The Economic Benefits of Publicly Funded Basic Research: A Critical Review. Research Policy, 30, 509-532.

https://doi.org/10.1016/S0048-7333(00)00091-3

SDGFP (South Dakota Department of Game, Fish and Parks) (2015). Strategic Plan 2016-2020. Pierre, South Dakota. https://gfp.sd.gov/userdocs/docs/strategic-plan-2.pdf

SDGFP (South Dakota Department of Game, Fish and Parks) (2019a). 2019 Annual Technical Fish Stocking Report. Pierre, South Dakota.

https://apps.sd.gov/GF56FisheriesReports/

SDGFP (South Dakota Department of Game, Fish and Parks) (2019b). Wildlife and Parks Budget Information. Pierre, SD: Division of Wildlife Budget Information. https://gfp.sd.gov/budget/

Tourism Economics (2017). Economic Impact of Tourism in South Dakota, 2017. https://sdvisit.com/sites/default/files/2018-06/17EcoImp Tourism Economics.pdf

USDA (2014). 2012 Census of Agriculture, Census of Aquaculture (2013), Volume 3, Part 2. AC-12-SS-2. Washington DC: United States Department of Agriculture.

https://www.agcensus.usda.gov/Publications/2012/Online Resources/Aquaculture/aqu acen.pdf

USFWS \& USCB (U.S. Fish and Wildlife Service and U.S. Census Bureau) (2018). 2016 National Survey of Fishing, Hunting, and Wildlife-Associated Recreation. Publication FHW/16-Nat(RV).

https://www.census.gov/content/dam/Census/library/publications/2018/demo/fhw16-n at.pdf

USFWS (U.S. Fish and Wildlife Service) (2001). Economic Effects of Trout Production by National Fish Hatcheries in the Southeast. Atlanta, GA: USFWS.

USFWS (U.S. Fish and Wildlife Service) (2006). Economic Effects of Rainbow Trout Production by the National Fish Hatchery System. Atlanta, GA: USFWS.

USFWS (U.S. Fish and Wildlife Service) (2020). National Fish Hatchery System. https://www.fws.gov/fisheries/nfhs/index.html

Whitehead, J. C., \& Aiken, R. (2007). Temporal Reliability of Willingness to Pay from the National Survey of Fishing, Hunting and Wildlife-Associated Recreation. Applied Economics, 39, 777-786. https://doi.org/10.1080/00036840500438996

Williams, D., \& Rank, A. D. (1998). Measuring the Economic Benefits of Research and Development: The Current State of the Art. Research Evaluation, 7, 7-30.

https://doi.org/10.1093/rev/7.1.17 